\title{
The Importance of Psychological Counseling to College Ideological and Political Education
}

\author{
Zhao Qiang \\ School of Electronic Science and Engineering, University of Electronic Science and Technology of China \\ Sichuan Chengdu 610054
}

Keywords: psychological counseling; college education; ideological politics

\begin{abstract}
College students undertake the hope and future of the motherland, meanwhile, they are the pillars of the country's future development. Therefore, it is necessary to attach importance to college students' ideological and political. In addition, the ideological and political education in colleges and universities plays an important role in the cultivation of good habits of college students and the future employment and development. However, there are many problems in the ideological and political education of students. Psychological counseling is believed to strengthen colleges and universities. Political education is important, which is discussed in detail in this paper.
\end{abstract}

\section{Introduction}

The progress of society has caused people's ideological concepts to undergo great changes. The teaching methods are also constantly innovating. The ideological and political education of colleges and universities should not only be done to complete the training tasks of college students but also to make students develop better and improve the comprehensive ability of competition. In the face of increasing competition trends and various problems in learning, we should communicate in a timely manner. Psychological counseling is a good way to draw the distance close to students and to carry out ideological and political education.

\section{The importance of psychological counseling to the ideological and political education in colleges and universities}

\subsection{Promoted the establishment of the core objectives of ideological and political education in colleges and universities}

The introduction of psychological counseling has made the ideological and political education in colleges and universities more clear and specific. Especially in recent years, college students have committed crimes or suicides, so it is necessary to strengthen the emphasis on college students' mental health problems. Traditional ideological and political education is only done as a teaching goal. In many cases, it is not possible to actually solve the problems faced by students. The mental counseling can timely solve their problems and guide them to avoid the occurrence of vicious incidents. At the same time, it also sets new goals for college ideological and political education, making it more humanized, and stimulates students' interest in learning knowledge in this aspect.

\subsection{It promotes the optimization of teaching methods of ideological and political education in colleges and universities}

Psychological counseling includes a variety of methods, the most common of which are as follows: First, guidance with encouragement. Encouraging students can promotes to increase their self-confidence, and helps them more calmly face problems in learning and life and solve problems positively. Second, guidance with perseverance. Many college students lacks sufficient perseverance rather than competence for the tasks. Enough perseverance is necessary whatever you do. Nothing can be accomplished by giving up halfway. Therefore, many psychological counseling teachers strengthen the perseverance of students with this method and encourage them to persist from the beginning to the end. Regardless of the outcome, the process of persistence deserves 
encouragement and praise. Third, guidance with transpositional consideration. Facing difficulties, many people may believe that others do not understand them and their sadness and pain. In this case, they can tell the same or similar experiences they once had by transpositional consideration, which would facilitates students to accept psychological counseling easily. The implementation of various methods enables students to better understand the importance colleges and universities attach on ideological and political education as well as the investment in teaching force, and urge them to work harder to improve themselves.

\subsection{It helps on the teaching stuff construction in ideological and political education in colleges and universities}

It is that trend of social development to strengthen the attention of university student 'mental health, the psychological consultation is the most direct way to solve the psychological problem of university students, and also meet the requirement of university ideological political education. However, the original teachers can not meet the psychological counseling needs of students. Therefore, the school has also improved the ideological and political level while expanding the psychological counseling teachers. In addition, to strengthen the psychological counseling team, we should not only complete the teaching tasks, but also combine political education with how to promote students' better growth, so as to push ideological and political education into a more professional perspective.

\section{Problems in the application of psychological counseling in current ideological and political education in colleges and universities}

\section{1 psychological counseling and ideological and political education are out of touch}

Ideological and political education is a compulsory course in the university. Although the teacher will also explain the relevant content of psychological counseling when teaching the relevant courses, it cannot solve the students' problems in fact. The biggest problem currently exists is the disconnection between psychological counseling and ideological and political education. It is that opinion of most university student that the ideological political curriculum is a mixed curriculum which is not carefully listened to in class. In addition, the school has fewer restrictions on students, and many times it does not force students to do anything, so it does not actually achieve the goal. In addition, the ideological and political courses offered by the school are not much different from those offered in middle and high schools. Teachers do not pay enough attention to the teaching methods of psychological counseling, which leads to the development of education.

\subsection{The imperfect construction of psychological counseling mechanism in colleges and universities}

Many schools have psychological counseling rooms, but they are often established in response to relevant policies. In fact, many students are not willing to go to the counseling room even if they have psychological problems. The main reason for this situation is psychological counseling. The mechanism is not perfect. College leaders and teachers have not placed psychological counseling in a more important position, and the connection and importance between psychological counseling and ideological political education have not yet been discovered. Therefore, they does not pay attention to the establishment and improvement of the psychological counseling room. There are some loopholes in the relevant system, which can not protect the privacy of the consulting students. In addition, most of times students do not think that some of their current psychological problems are mental illnesses. They think that it is only a small matter, which is one of the reasons why the psychological counseling system cannot be perfected.

\subsection{The effect of psychological counseling is not ideal}

The effect of psychological counseling is not significant. It is currently a common phenomenon. The author believes that it is mainly caused by the following two reasons: First, the professionalism of the psychological counseling teacher is not strong, and it does not put psychological counseling 
in a more important position. At the same time, psychological counseling is a highly demanding job, which is impossible for many colleges and universities. Second, the students will unconsciously develop a kind of awe of the teachers. Therefore, when they are confused, they will talk to their classmates and friends rather than looking for a teacher, plus some problems in the psychological counseling of colleges and universities. The effect of psychological counseling is not ideal.

\section{Innovative Thinking on the Application of Psychological Guidance in College Ideological and Political Education}

\subsection{Establish a mutual trust and respect between teachers and students}

The teacher's understanding of the students should not only be limited to the academic performance, but also to understand the life of the students from the aspects of family, living conditions, interpersonal communication and so on. However, as the students raised above have a natural sense of respect for the teacher, the teachers of ideological and political education should get along with the students in the way of friends in the process of teaching. Let students feel the equal and trusted relationship with the teacher in the process of communication. Only then will the students share the things they encounter with the teachers, which will help the teacher to better conduct psychological counseling. Students have a deep understanding of the difficulties and frustrations encountered in life and learning with a positive and optimistic attitude.

\subsection{Pay attention to the psychological world of students and strengthen the construction of psychological counseling system}

The improvement of the level of science and technology has made the development of the Internet era faster. People are surrounded by a large amount of information every day, and students face more challenges in their lives. A small problem in the process of getting along with classmates will lead to a big dispute. The intense study life, the one-sidedness of the education system and other reasons will have a certain impact on the mental health of college students. What follows is some negative energy. If not handled well, these negative energy will cause great trouble to students and even affect normal life and study. Therefore, when carrying out ideological and political education, colleges and universities should pay more attention to the psychological world of students and strengthen the establishment of psychological counseling system. Psychological counseling teachers should respect each colleague in the process of teaching, understand the most real thoughts in the heart, and reverse the current state of mind through continuous communication and guidance, so that they can vent their negative emotions and maintain a good mentality.

\subsection{Understand the value orientation of students and give students the opportunity to develop freely}

Most of the high school stage is in an intense review, so the university stage has a huge impact on the formation of student values. Ideological and political education is of course important, but it should also give students a corresponding development space and pay attention to the value orientation of students. For example, by organizing a variety of campus activities, students can fully demonstrate their opportunities, so that they can continuously improve themselves, explore their potential and affirm their value. The ultimate goal of psychological counseling is also to encourage students to face life with a more positive sunshine attitude. Therefore, the emphasis on student values can not only improve the level of political education, but also improve students' ability.

\section{Conclusion}

In short, the current social form has caused college students to face tremendous pressure in both employment and daily life, especially in the pre-employment period, many college students are confused. By communicating with students and solving problems in a timely manner, teachers can help them establish a correct life orientation and improve their level of thinking. Through simple psychological counseling, they can help them better solve their learning and work problems , better 
for their development and contribution to the progress of society.

\section{References}

[1] Ning Xu. On the Realistic Value of Psychological Guidance to College Ideological and Political Education [J]. Education Modernization, May 8, 2017.

[2] Wanjia Kuang. Humanistic Care and Psychological Guidance in the View of Ideological and Political Education in Colleges and Universities[J]. Journal of Jiamusi Vocational College, January 15, 2016.

[3] Xin Li. Innovative research on constructing humanistic care and psychological counseling system in colleges and universities [J]. Modern Communication, March 15, 2015. 